\title{
The Murder of George of Cappadocia and the Violent Pagan Image in Ammianus Marcellinus
}

\author{
Shunsuke Kosaka \\ Tohoku University, Sendai, Japan \\ skosaka@m.tohoku.ac.jp
}

\section{Summary}

This paper focused on three main issues regarding the brutal murder of George of Cappadocia on 24 December $361 \mathrm{CE}$ in Alexandria and the question of whether the "pagans" attempted to prevent the cult of the martyr. First, an examination of the sources regarding the murderers of George found that the Alexandrian crowd did not only consist of pagans. Instead, everyone who had suffered from the tyranny of George could be possible assailants. Second, Ammianus' report that the intention of the people was to defile the victims' remains is highly contested. Regarding fourth-century Alexandria, it is impossible to find any evidence that refers to such an attempt. Third, his text exposed a somewhat ruthless image of pagans as presented by Christian authors such as Prudentius. Despite Ammianus being not a Christian himself, his account reflects the images of the cruel pagans fabricated by Christians, thus allowing us to acknowledge the Christianised view of pagans in the work of the last great Latin historian.

\section{Keywords}

murder of George of Cappadocia - pagans' role - Ammianus Marcellinus

\section{Introduction}

On 24 December $361 \mathrm{CE}$, the people of Alexandria brutally murdered George of Cappadocia, who was appointed as the city's bishop by Emperor Constantius

* The author would like to thank the participants at the gth APECSs conference for valuable advice and Enago (www.enago.jp) for the English language review. 
II in 357. However, after the emperor's death on 3 November 361 , the Alexandrian people imprisoned George due to their disapproval of his tyrannical and coercive acts. After approximately one month, the people dragged George and his fellow imperial officers, Diodorus and Dracontius, through every part of the city, murdered them, flung their corpses onto camels and carried them to the shore. The outrageous crowd then set the bodies (as well as those of the camels) on fire and cast the ashes into the sea. The fourth-century historian Ammianus Marcellinus reported the disposal of the victims' corpses as follows:

Not content with this [murder of George and the officers], the inhuman mob loaded the mutilated bodies of the slain men upon camels and carried them to the shore; there they burned them on a fire and threw the ashes into the sea, fearing (as they shouted) that their relics might be collected and a tomb built for them, as for others who, when urged to abandon their religion, endured terrible tortures, even going so far as to meet a glorious death with unsullied faith; whence they are now called martyrs. ${ }^{1}$

A well-known hypothesis is that the "pagans" in the city of Alexandria murdered George, and in doing so, they effectively prevented the veneration of their relics by scattering the remains into the sea. ${ }^{2}$ According to Haas, the Alexandrian pagan community had evolved as the counterpart of the Christians

1 Ammianus Marcellinus, Res Gestae, 22.11.10 (ed. by W. Seyfarth, Leipzig, 1978): "quo non contenta multitudo immanis dilaniata cadauera peremptorum camelis imposita uexit ad litus isdemque subdito igne crematis cineres proiecit in mare id metuens, ut clamabat, ne collectis supremis aedes illis extruerentur ut reliquis, qui deuiare a religione compulsi pertulere cruciabiles poenas ad usque gloriosam mortem intemerata fide progressi et nunc martyres appellantur." Transl. by J.C. Rolfe, Ammianus Marcellinus History, vol. 2 (LCL, 315), Cambridge, MA-London, 1940, p. 263. However, the present author has replaced the word "church" with "tomb" ("aedes" in Latin).

2 C. Haas, "The Alexandrian riots of 356 and George of Cappadocia," Greek, Roman and Byzantine Studies, 32 (1991), pp. 281-301; idem, "Alexandria's Via Canopica: political expression and urban topography from Augustus to 'Amr Ibn al-'As," Bulletin de la Société Archéologique d'Alexandrie, 45 (1993), pp. 123-138; J. den Boeft, J.W. Drijvers, D. den Hengst, H.C. Teitler, Philological and Historical Commentary on Ammianus Marcellinus XXII, Groningen, 1995, pp. 196-212; C. Haas, Alexandria in Late Antiquity: topography and social conflict, Baltimore, 1997, pp. 280-295; H.C. Brennecke, "Christliche Quellen des Ammianus Marcellinus?," Zeitschrift für Antikes Christentum, 1 (1997), S. 226-250; D.G. Kyle, Spectacles of Death in Ancient Rome, London, 1998, p. 264, n. 75; H.A. Drake, "The curious case of George and the camel," in: Studies of Religion and Politics in the Early Christian Centuries, ed. by D. Luckensmeyer, P. Allen, Virginia, QLD, 2010, pp. 173-193. Cf. M. Caltabiano, "L'assassinio di Giorgio di Cappadocia (Alessandria, 361 
during the fourth century. Although the pagans in the city primarily lacked a firm institution and a religious identity, a rigid religious community emerged from the rapid spread of Christianity and the opposition to it. In the middle of the century, oppression against both pagans and the followers of Athanasius under Arian Emperor Constantius II resulted in several violent conflicts. Thus, George and his anti-pagan campaign represented imperial religious policies at that time. The pagans in the city were especially disturbed by the prohibition against pagan sacrifices and seizure of their temple. His insulting comments towards the temple itself intensified the pagans' disaffection.

As stated earlier, after presenting the victims' corpses in a procession throughout the city, the enraged people burned them on the shore and scattered the ashes into the sea. This act suggests that the pagan mob attempted to prevent George from being venerated as a martyr. In fact, some pagan authors in the fourth century expressed hostile attitudes towards the practice of venerating relics. ${ }^{3}$ Emperor Julian condemned it as a veneration of the impure corpse and grave, ${ }^{4}$ while Eunapius of Sardis, a Greek writer and the author of the Lives of the Sophists, observed that Christians collected the bones of criminals and venerated them. ${ }^{5} \mathrm{~A}$ similarly hostile view against the cult of the martyr was described in a letter from a teacher of Madaura to Augustine. ${ }^{6}$ These feelings of resentment appear to correspond with the account of the incident provided by Ammianus Marcellinus.

However, recent trends suggest that the framework of the conflict between pagans and Christians needs to be revised. More specifically, the arguments on the concept of pagans, ${ }^{7}$ the diversity of religious identity that coexists within

d. C.)," Quaderni catanesi di studi classici e medievali, 7 (1985), pp. 17-59, state that the murderers included both pagans and Christians. The present author also adopts this conclusion.

3 See P. Brown, The Cult of the Saints: its rise and function in Latin Christianity (enlarged edition, Chicago - London, 2014 (first ed. 1981), pp. 6-8. Furthermore, on the cult of the martyr, see H. Delehaye, Les origines du culte des martyrs, Brussels, 1933; J. Leemans, W. Mayer, P. Allen, B. Dehandschutter, 'Let us die that we may live': Greek homilies on Christian martyrs from Asia Minor, Palestine and Syria (c. AD $350-A D$ 450), London - New York, 2003, pp. 3-14; L. Grig, Making Martyrs in Late Antiquity, London, 2004, pp. 86-94.

4 Julian, Adversus Galilaeos, 335 B-335D (ed. by W.C. Wright (LCL, 157), Cambridge, MA - London, 1923). Regarding Julian's criticisms against the cult of relics, see J. Torres, "Emperor Julian and the veneration of relics," Antiquité Tardive, 17 (2009), pp. 205-214.

5 Eunapius, Vitae Sophistarum, 6.11.8-9 (ed. by G. Giangrande, Rome, 1956).

6 Augustine, Epistula 16 (ed. by A. Goldbacher (CSEL, 34), Vienna, 1895).

7 A. Cameron, The Last Pagans of Rome, Oxford, 2011, pp. 14-32. 
individuals ${ }^{8}$ and the problems of religious violence ${ }^{9}$ impel us to reconsider what occurred in the late antique Alexandria. Haas, indeed, also noticed the necessity of reconsidering the religious and social setting in Alexandria. ${ }^{10}$ Therefore, it is important to examine the underlying cause the brutal murder of George, its actors and the meaning of the insults towards his corpse.

In sum, the present paper makes three claims. First, the cause behind these murders in Alexandria was not merely confined to the pagans. In fact, during the Late Antiquity, the violent conflicts in Alexandria were due to various reasons, one of which was religious. Scholars tend to place the murder of George within such a context. However, an in-depth investigation of the sources leads us to different interpretations. Second, an inquiry into the casualties of violence in fourth century Alexandria indicates that the murderers did not aim to prevent the cult of the martyr. Third, by investigating Christian sources, it becomes evident how the images of pagans as cruel and severe people emerged and developed. This gives room for a new interpretation regarding the social and religious background of the late antique Alexandria and the relationship between Christian sources and Ammianus Marcellinus.

\section{$2 \quad$ The Murderers of George of Cappadocia}

The incident in question was described in numerous works by fourth and fifth century historians who offered diverse interpretations. Nevertheless, many of the works shared the perspective that the murderers were Hellenes ("E $\mathrm{\lambda} \eta \nu \varepsilon \varsigma$ ), i.e., pagans. ${ }^{11}$ Despite the substantial influence that these authors have on

É. Rebillard, Christians and Their Many Identities in Late Antiquity, North Africa, 200-450 $C E$, Ithaca - London, 2012.

9 H.A. Drake, "Intolerance, Religious Violence, and Political Legitimacy in Late Antiquity," Journal of the American Academy of Religion, 79 (2011), pp. 193-235; J.N. Bremmer, "Religious Violence between Greeks, Romans, Christians and Jews," in: Violence in Ancient Christianity: victims and perpetrators, ed. by A.C. Geljon and R. Roukema, Leiden - Boston, 2014, pp. 8-30.

10 C. Haas, "Hellenism and Opposition to Christianity in Alexandria", in Ancient Alexandria between Egypt and Greece, ed. by W.V. Harris, G. Ruffini, Leiden - Boston, 2004, pp. 217229.

$11 \quad$ Epiphanius, Panarion, 68.11.1-2,76.1 (ed. by K. Holl, J. Dummer (GCS, 37), Berlin, 1985); Philostorgius, Historia Ecclesiastica, 7.2 (ed. by J. Bidez, F. Winkelmann (GCS, 21), Berlin, 1981); Socrates, Historia Ecclesiastica, 3.2 (ed. by G.C. Hansen (GCS, N. F. 1), Berlin, 1995); Sozomen, Historia Ecclesiastica, 5.7 (ed. by J. Bidez, G.C. Hansen (GCS, N. F. 4), Berlin, 1995); Chrononicon Paschale, a.362 (ed. by L.A. Dindorf (CsHB, 11), Bonn, 1832). Regarding 
contemporary studies, it is worth noting that all of those who blamed the pagans for the incident are subjects of criticism. As Caltabiano indicated, ${ }^{12}$ it is possible to determine church historians' anti-pagan perspectives and the controversy surrounding the agitators. To begin with, for Philostorgius, who emphasised pagan violence during the reign of Emperor Julian, it was important that the incident occurred as soon as Julian had seized power. ${ }^{13}$ Philostorgius, as a member of the Eunomian party, ${ }^{14}$ further added that Athanasius seduced the pagans. Subsequently, both Socrates and Sozomen attempted to refute this claim $^{15}$ and in doing so, Socrates presented a new explanation. While clearing ground for church building in place of the Temple of Mithras, which Emperor Constantius II had conferred on them, George and his fellow Christians found a number of skulls that they exposed and ridiculed as a mysterious trait of the pagans. Naturally, this infuriated the pagans in the city. ${ }^{16}$ Sozomen, repeating this narrative presented by his predecessor with alternation, supplemented the abuse and inhibition against the pagans. ${ }^{17}$ Although they shared the antipagan view with Philostorgius, ${ }^{18}$ both highlighted the anti-pagan campaign by George. Thus, the church historians during the fifth century solely attributed the murder of George to the conflict between the pagans and the Christians, which, in turn, calls for an investigation of the earlier sources.

Soon after the incident in Alexandria, Emperor Julian addressed the Alexandrians via an official letter in which he condemned them for the exhibited violence and addressed the demos of the city as followers of Alexander and "the most holy Serapis". ${ }^{19}$ This wording suggests that the murderers primarily consisted of pagans. ${ }^{20}$ However, Hunt rightly observed that these words were a

\footnotetext{
the date of the Chronicon Paschale, see Michael Whitby, Mary Whitby, Chronicon Paschale 284-628 AD, Liverpool, 1989 .

12 Caltabiano, "L'assassinio di Giorgio," pp. 52-59.

13 Philostorgius, Historia Ecclesiastica, 7.1-2.

14 P.R. Amidon, Philostorgius: Church History, Atlanta, 2007, pp. xiii-xxiii.

15 Socrates, Historia Ecclesiastica, 3.3.1; Sozomen, Historia Ecclesiastica, 5·7.4.

16 Socrates, Historia Ecclesiastica, 3.2.2-10. Socrates might have borrowed this episode from Rufinus, Historia Ecclesiastica, 11.22 (ed. by S. Schwartz, T. Mommsen (GCS, 9), Leipzig, 1908). See P. Van Nuffelen, Un héritage de paix et piété: étude sur les histoires ecclésiastiques de Socrate et de Sozomène, Leuven, 2004, p. 464.

17 Sozomen, Historia Ecclesiastica, 5·7.4-7.

18 R.J. Penella, "Julian the persecutor in fifth century church historians," Ancient World, 24 (1993), pp. 31-43. It seems that Epiphanius shared the same viewpoint.

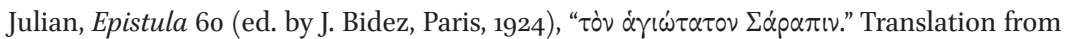
W.C. Wright, The Works of Emperor Julian, vol. 3 (LCL, 157), London, 1923, p. 61. 
mere expression of Emperor Julian's own perspective that the Alexandrian people shared the same religious views as him. ${ }^{21}$ Thus, it is incorrect to refer to this particular letter as evidence concerning the religious identity of the murderers.

Let us now focus on the document called Historia Acephala, which narrates the history of the church of Alexandria during the episcopate of Athanasius, although the shortened and translated versions of it exists nowadays. ${ }^{22}$ According to this text, the victims were annihilated by "almost all the people of that city." ${ }^{23}$ Ammianus Marcellinus in his Res Gestae also confirmed that "all the populace" seized the victims. ${ }^{24}$ For both authors, religious difference of the assailants had less significance. To impress on its readers the animosity of the Alexandrian people against George, these words might have exaggerated the extent of the incident. It is also doubtful that "almost all the people" assaulted George. Nevertheless, it is important that the author of Historia Acephala felt no necessity to distinguish the pagans from the inhabitants in the city. Therefore, the murderers of George were not exclusively pagans, but they included broader groups in the city.

Several criticisms towards George that are attested in some sources justify the above-mentioned argument. George was notorious for his avarice, Arianism, connection with Emperor Constantius II and anti-pagan campaign. ${ }^{25}$ Moreover, Caltabiano indicated that the intrusion into the social economy in Alexandria by George caused abhorrence towards himself. ${ }^{26}$ Epiphanius described that George monopolised nitre mining, papyrus and salt production ${ }^{27}$

21 E.D. Hunt, "Christians and Christianity in Ammianus Marcellinus," Classical Quarterly, 35 (1985), pp. 186-200 (see pp. 191-192).

A. Martín and M. Albert, Histoire «Acéphale» et Index Syriaque des Lettres Festales d'Athanase d'Alexandrie (sc, 317), Paris, 1985, pp. 11-121.

23 Historia Acephala, 2.10 (ed. by Martin, Histoire «Acéphale», p. 148): "pene omnis populus illius ciuitatis."

24 Ammianus Marcellinus, Res Gestae, 22.11.8: "plebs omnis." Translation from Rolfe, p. 261. However, we should not overlook that Ammianus might have deliberately avoided the terms with religious connotation. See Hunt, "Christians in Ammianus"; J. Matthews, The Roman Empire of Ammianus (with a new introduction), Ann Arbor, 2007 (1st ed., London, 1989), pp. 424-451.

25 Critic of Arianism: Epiphanius, Panarion, 68.1-2; 76.1. Connection with the emperor: Ammianus Marcellinus, Res Gestae, 22.11.5-6. Avarice: Epiphanius, Panarion, 76. 4-6; Gregory of Nazianzus, Oratio 21.16 (ed. by J. Mossay (sc, 270), Paris, 1980). Anti-pagan campaign: Ammianus Marcellinus, Res Gestae, 22.11.7; Julian, Epistula, 6o. See Haas, Alexandria, pp. 280-295.

26 Caltabiano, "L'assassinio di Giorgio," pp. 38-47.

$27 \quad$ Epiphanius, Panarion, 76.1.5. 
and besides these industrial businesses, the people in the city might have had to pay George for inhumation. ${ }^{28}$

These aforementioned causes are sufficient to infer the hostility exhibited by the inhabitants of Alexandria towards George. Moreover, it seems reasonable to conclude that it was not the religious conflict between the pagans and Christians, but the disapproval of George that eventually fuelled the violence.

\section{$3 \quad$ Cremating the Victims}

As mentioned above, Ammianus Marcellinus reported that the murderers burned the victims' bodies and dispersed the ashes in the sea since they feared that the remains could be gathered and tombs would be built to revere the victims as martyrs. ${ }^{29}$ It has been established that the murderers deliberately attempted to prevent the victims from becoming objects of Christian veneration. ${ }^{30}$ By the time that this incident occurred, the Alexandrian people could have observed the cult of the martyrs and relics as visible phenomenon. In this regard, archaeological studies provide sufficient evidence. In fourth century Alexandria, Christians had constructed a number of church buildings and martyria. The martyrium of St Mark, for example, was located just outside the east wall of the city. During that century, Abu Mina, situated southwest of Alexandria, developed as a pilgrimage town around the tomb of St Menas. ${ }^{31}$ The inhabitants in Alexandria were probably aware of this development influenced by Christianity. We may recall that Eunapius indeed criticised the cult of the martyrs performed by the monks in Alexandria. ${ }^{32}$ Given that the pagans in the city shared the same conviction with Eunapius, it is plausible that they took the occasion to deprive the Christians of the cult's sources through a riot. However, we must scrutinize Ammianus' statement that the the murderers "shouted" (clamabat) the reason why the bodies of the victims had to be destroyed. This "shouting" seems too lengthy and descriptive for such a frenzied crowd. ${ }^{33}$

28 Epiphanius, Panarion, 76. 1. 6-7.

29 Ammianus Marcellinus, Res Gestae, 22.11.10.

30 See n. 2. Moreover, L. Cracco-Ruggini, "Les morts qui voyagent: le repatriement, l'exil, la glorification," in: La mort au quotidien dans le monde romain, ed. by F. Hinard, Paris, 1995, pp. 117-134 (see p. 125).

$31 \quad$ Haas, Alexandria, pp. 213-214; S. Bangert, "The archaeology of pilgrimage: Abu Mina and beyond," in: Religious Diversity in Late Antiquity, ed. by D.W. Gwynn, S. Bangert, Leiden and Boston, 2010, pp. 293-327; J. McKenzie, The Architecture of Alexandria and Egypt: $c$. 300 BC to AD 70o, New Haven and London, 2007, pp. 236-248, 288-295.

32 Eunapius, Vitae Sophistarum, 6.11.8-9.

33 I am indebted to Dr. S. Ohtani's valuable insights regarding this point. As seen in the writings by Ammianus, some shouts of the people are usually short. For example, Ammianus 
This therefore implies that either Ammianus or his source regarding George's death fabricated this sentence, which merely aimed to emphasise the savagery of the murderers.

Furthermore, judging from the other cases of violence towards Christians in Alexandria during the fourth century, there is no conclusive evidence of attempted preventions of the cult of the martyr. First, in the spring of 339, when the Arian Gregory was appointed as bishop of Alexandria, Philagrius, the pre-

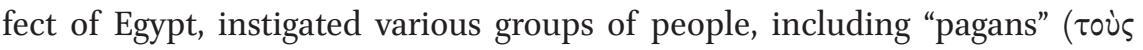

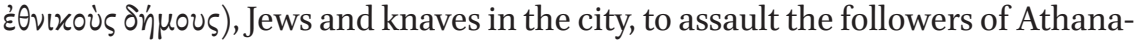
sius in the church called Cyrinus. ${ }^{34}$ Athanasius described that many were killed without mentioning how the corpses were treated thereafter. Next, in early 356 , Syrianus, the military commander of Egypt, and his army irrupted into the church of Theonas and similarly assailed the Christians. ${ }^{35}$ According to the petition cited in Arian History by Athanasius, the assailants slaughtered many people praying in the church. Then, the imperial notary Hilarius, who accompanied Syrianus, ordered the army to take the victims' bodies (except for the virgins) out of the church. However, there is no evidence regarding the elimination of the remains, as in the case of George. Rather, the petitioners asserted that the deserted bodies testified the illegality of the commanders and that the bodies of the virgins were inhumed as martyrs. ${ }^{36}$ It must be noted that, in this case, although the imperial officer and his army turned upon the victims, the Christians were allowed to at least bury their members.

Finally, a well-known insurrection between pagans and Christians led to the destruction of Serapeum at the end of the fourth century. ${ }^{37}$ Although the reports of Church historians regarding the course of this incident are contradictory, none of them make an explicit reference to any cremation of the victims' remains. According to Rufinus, the pagans (gentiles) took some Christians into the temple and compelled them to sacrifice. Due to their opposition, the pagans killed them by "fastening some to the gibbets and breaking the legs of others and pitching them into the caverns." ${ }^{38}$ Rufinus did not refer to the fate

Marcellinus, Res Gestae, 15.5.34: "Siluanus deuictus est"; 31.1.2: "uiuus ardeat Valens."

Athanasius, Epistula encyclica, 3-4 (ed. by H.-G. Opitz, Berlin - Leipzig, 1935-1941, pp. 169-177); Historia Arianorum, 10 (ed. by Opitz, 1935-1941, pp. 183-230).

Athanasius, Historia Arianorum, 81; Historia Acephala, 1.10.

36 Athanasius, Historia Arianorum, 81.2,9.

37 Regarding this subject, see Haas, Alexandria, pp. 159-169; J. Hahn, "The conversion of the cult statues: the destruction of the Serapeum $392 \mathrm{AD}$ and the transformation of Alexandria into the 'Christ-Loving' City," in: From Temple to Church: destruction and renewal of local cultic topography in late antiquity, ed. by J. Hahn, S. Emmel, U. Gotter, Leiden - Boston, 2008, pp. $335-365$.

38 Rufinus, Historia Ecclesiastica, 11.22: "alios patibulis adfigentes, alios confractis cruribus in speluncas praecipitantes.” Translation from P.R. Amidon, The Church History of Rufinus of 
of the bodies. Similarly, both Socrates and Sozomen described that the pagans ("E $\lambda \eta \eta \varepsilon \varsigma)$ assaulted the Christians without mentioning how the dead were treated. ${ }^{39}$ It is most likely that the assailants left the bodies after which their fellow Christians buried them.

From the aforementioned evidence, it can be concluded that Ammianus' account of the murder of George does not represent the genuine purpose of the murderers, but it is instead his (or his source's) interpretation of the crowd's behaviour. Another interpretation regarding this matter has been offered by Haas as follows: "the entire process (execution or flogging, ceremonial parade and/or dragging of body, cremation) had a long tradition in Alexandria and constituted a carefully structured ritual of civic purgation." ${ }^{20}$ His argument is supported by several examples in the history of Alexandria. For example, when Jews were persecuted in Alexandria in $38 \mathrm{CE}$, they were "dragged through the whole city, and trampled on, and thus completely made away with till not a part of them was left which could receive the burial which is the right of all."41 Then, during the Decian persecution, two Christian martyrs were flung onto camels, dragged throughout the city and burned with quicklime. ${ }^{42}$ Finally, more than one hundred years after the murder of George, in 457, the populace of the city attacked the patriarch Proterius after which his body was dragged around the city and eventually cremated. ${ }^{43}$ Haas argued that the cremation was the reverse of the traditional esteem for corpses that was specific to Egypt. ${ }^{44}$

Although the validity of Haas' anthropological interpretation is not discussed in this paper, ${ }^{45}$ the present author provides another explanation. Kyle stated that the denial of burial and corpse abuse denotes "a form of damnation

Aquileia: books 10 and 11, New York - Oxford, 1997, p. 79.

39 Socrates, Historia Ecclesiastica, 5.16; Sozomen, Historia Ecclesiastica, 7.15.

40 Haas, Alexandria, p. 293. He argued this point more closely in Haas, "Alexandria's Via Canopica," pp. 134-137.

41 Philo, In Flaccum, 65 (ed. and trans. by F.H. Colson (LCL, 363), London - Cambridge, 1941,

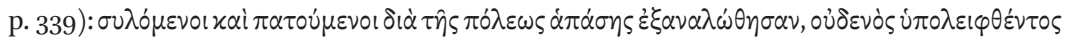

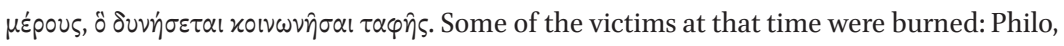
In Flaccum, 66-71.

42 Eusebius, Historia Ecclesiastica, 6.41.15 (ed. by S. Schwartz (GCS, 9), Leipzig, 1908).

43 Evagrius, Historia Ecclesiastica, 2.8 (ed. by J. Bidez and L. Parmentier, The Ecclesiastical History of Evagrius, with the Scholia, London, 1898; repr. New York, 1979).

44 Haas, "Alexandria's Via Canopica," p. 135. Regarding Egyptian thought on the burning of the body, see A.D. Nock, "Cremation and burial in the Roman Empire," Harvard Theological Review, 25 (1932), pp. 321-359 (see pp. 341-344).

45 Haas cited M. Douglas, Purity and Danger, London, 1966 (Haas, "Alexandria's Via Canopica," p. 135, n. 74). I consulted the Japanese translation (trans. by T. Tsukamoto, Tokyo, 1995 (new ed.)). 
beyond death" in the Roman world. ${ }^{46}$ Although his research on this point covers the cases until the mid-third century, it is possible to find a parallel seven years before the death of George. In Antioch in 354, Domitian, the praetorian prefect of the East, and Montius, the quaestor of the palace were lynched by an army instigated by Gallus Caesar. ${ }^{47}$ After seizing and binding the two imperial high officers with rope, the incensed army dragged them through the main street after which their remains were trampled, torn and eventually hurled into the river. In this case, the murderers harmed two bodies as the retribution for their disobedience to Gallus Caesar. This incident in Antioch leads us to presume that the cremation of George in Alexandria was the severest punishment for his evildoing.

\section{Memory of Persecution Reflected by Ammianus Marcellinus}

The previous argument regarding the incident and Ammianus' text leads us to further consideration. Why did Ammianus, not being Christian, ${ }^{48}$ offer such an explanation on the cremation of George? To investigate this issue, the time and place beyond fourth century Alexandria needs to be expanded. There are several instances of pagans' cruel behaviour towards the remains of the martyrs described in Christian texts. Brennecke revealed that Ammianus might have relied on Christian sources when he described the murder of George. Brennecke suggested that one source was the so-called Anonymous Homoean History compiled in the late fourth century, which is now lost. ${ }^{49}$ However, the present author does not explicitly claim that Ammianus utilised this source. ${ }^{50}$

$46 \quad$ Kyle, Spectacles of Death, pp. 131-133 (quotation from p. 131).

47 Ammianus Marcellinus, Res Gestae, 14.7.9-16. Regarding the turbulence in Antioch, see Matthews, Roman Empire of Ammianus, pp. 33-35.

48 Regarding Ammianus' religiosity, see Hunt, "Christians in Ammianus”; R.L. Rike, Apex Omnium: religion in the Res Gestae of Ammianus, Berkeley, 1987; E.D. Hunt, "Christianity in Ammianus Marcellinus Revisited," in: Studia Patristica, vol. xxIv: historica, theologica et philosophica, gnostica, ed. by E.A. Livingstone, Leuven, 1993, pp.108-113; T.D. Barnes, Ammianus Marcellinus and the Representation of Historical Reality, Ithaca - London, 1998, pp. 79-94; J.P. Davies, Rome's Religious History: Livy, Tacitus and Ammianus on their gods, Cambridge, 2004, pp. 226-285; Matthews, Roman Empire of Ammianus, pp. 424-451.

49 Brennecke, "Christliche Quellen des Ammianus." His argument reinforced the assumption suggested by J. Bidez. See Caltabiano, "Lassassinio di Giorgio," p. 29. On the so-called Anonymous Homoean History, see Amidon, Philostorgius, pp. 205-238.

$5^{0}$ Some studies have recognised that Ammianus possibly used the dissolved Christian source. G. Kelly, Ammianus Marcellinus: the allusive historian, Cambridge, 2008, pp. 322331; D.B. Levenson, "The ancient and medieval sources for the Emperor Julian's attempt to rebuild the Jerusalem temple," Journal for the study of Judaism, 35 (2004), pp. 409-46o (see 
Nevertheless, Brennecke's view is extremely important for this question since it indicates that the Christian understanding of the Alexandrian mob burning George influenced Ammianus' report. Thus, since pagans are found in Christian accounts, a further examination regarding the instances of the violent pagans attempting to prevent the cult of relics should be conducted.

The apprehension surrounding the cult of relics has already appeared in the Martyrdom of Polycarp, composed in the mid-second century. According to this work, after the death of Polycarp, many Christians aspired to receive his remains, which were regarded as "holiness." The opponents of Christians, especially Jews (as the author states), made an effort to prevent them from doing so by petitioning the governor not to yield the body of Polycarp. Otherwise, "they [the followers of Polycarp] desert the one who was crucified and begin to worship this one." ${ }^{51}$ It is impossible to conclude that this report precisely describes either the event or at least the hostility towards the cult of relics at the time ${ }^{52}$ since there is a possibility that the passages were interpolated before Eusebius cited them in his Church History. ${ }^{53}$

The next instance of the preclusion occurred in the period of "Great Persecution." As reported by Eusebius, in Nicomedia in the early 304, Christians who were accused of setting fire to the imperial palace were executed. Some imperial servants among the victims were buried, but later, their masters exposed the corpses from the tombs. Eusebius observed that they thought "as they [the martyrs] lay in their graves some people would worship them in the belief that they were gods." 54 Besides, Lactantius, who was in Nicomedia during the same

pp. 418-419, n. 34). Cf. R.W. Burgess, Studies in Eusebian and Post-Eusebian Chronography, Stuttgart, 1999 shows another possibility concerning the reconstruction of the lost source. The Martyrdom of Polycarp, 17.1-3 (ed. by B. Dehandschutter, "An updated edition of the Martyrdom of Polycarp," in: Polycarpiana, ed. by J. Leemans, Leuven - Paris - Dudley, MA,

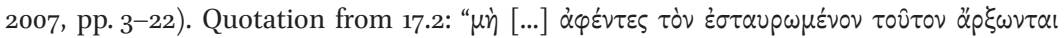
$\sigma \varepsilon \hat{\beta} \varepsilon \sigma \theta \alpha$ ”. Translation from B.D. Ehrman, The Apostlic Fathers, I (LCL, 24), Cambridge, MA - London, 2003, p. 391. Cf. É. Rebillard, The Care of the Dead in Late Antiquity, trans. by E.T. Rawlings, J. RoutierPucci, Ithaca - London, 2009, pp. 96-97.

53 Eusebius, Historia Ecclesiastica, 4.15. Regarding a study on the Martyrdom of Polycarp, see B. Dehandschutter, “The Martyrium Polycarpi: a century of research," in: Aufstieg und Niedergang der römischen Welt: Geschichte und Kultur Roms im Spiegel der neueren Forschung II 27. 1, ed. by W. Haase, Berlin - New York, 1993, pp. 485-522; idem, "Research on the Martyrdom of Polycarp: 1990-2005," in: Polycarpiana, ed. by J. Leemans, Leuven - Paris - Dudley, MA, 2007, pp. 85-92.

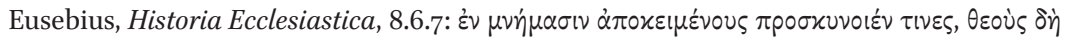

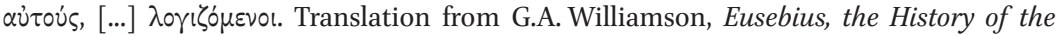
Church from Christ to Constantine, Harmondsworth, 1965, p. 334. Regarding this persecution, see T.D. Barnes, Constantine and Eusebius, Cambridge, MA - London, 1981, p. 24. 
time as this persecution, ${ }^{55}$ described that the bodies of the martyrs were burned and the collapsed bones were scattered, "so that no place of burial even exists - as if the aim of those who confess God were to have lots of visits to their own tombs, rather than go to God themselves." ${ }^{56}$ Despite these claims, we should not overlook that the authorities had another intention; i. e. the prevention of a congregation at the martyr's tomb, as Rebillard pointed out. ${ }^{57}$ In 257 , Emperor Valerian ordered that Christians should not gather around or enter the cemetery, which included the tombs of the martyrs. ${ }^{58}$ After comparing these two cases, it seems reasonable to suppose that the imperial government developed their method of inhibiting Christians from assembling.

However, the statements by both Eusebius and Lactantius regarding the demolition of the bodies in Nicomedia are still important. Their definition would also help formulate the image of the violent pagan who loathed the cult of the relic. It is possible to determine what verifies this in Peristephanon by Prudentius, the collection of the fourteen hymns written in the late fourth century in praise of the martyrs. ${ }^{59}$ First, the hymn of Vincent of Saragossa, executed in 304, describes the atrocity against his body. After his death, Datianus, the governor of Spain, stated:

But still the last resource remains, to punish him even in death. To deliver his body to the wild beasts or give it to the dogs to tear. Forthwith, I shall

Eusebius' case is slightly different from the incident in Alexandria. Uncovering the remains of Christians is attested in other sources: Tertullian, Apologeticum, 37.2 (ed. by E. Dekkers (CCL, 1), Turnholt, 1954, pp. 77-171); Rufinus, Historia Ecclesiastica, 11.28; Sozomen, Historia Ecclesiastica, 5.9. Nevertheless, it is worth investigating the remarks of Eusebius since others did not refer to the prevention of the cult of the martyr. By the same reason, I exclude some examples of scattering the ashes or disposal of the remains of martyrs in rivers or seas. See Kyle, Spectacles of Death, pp. 242-264.

55 E.D. Digeser, The Making of a Christian Empire: Lactantius \& Rome, Ithaca - London, 2000, pp. $1-17$.

56 Lactantius, Divinarum Intituonum, 5.11.6 (ed. by S. Brandt (CSEL, 19), Vienna, 189o): "quasi uero id adfectent qui deum confitentur, ut ad eorum sepulchra ueniatur, ac non ut ipsi ad deum ueniant." Translation from A. Bowen, P. Garnsey, Divine Institutes, Liverpool, 2003, p. 303; Lactantius, De Mortibus Persectiorum, 21.11 (ed. by J. Moreau (sC, 39), Paris, 1954).

57 Rebillard, Care of the Dead, p. 97.

$5^{8}$ Acta proconsularia Cypriani, 1 (ed. by G. Hartel (cSEL, 3. 3), 1871, pp. cx-cxiv); Eusebius, Historia Ecclesiastica, 7.11.10.

59 Regarding Prudentius and Peristephanon, see A.-M. Palmer, Prudentius on the Martyrs, Oxford, 1989; M.J. Roberts, Poetry and the Cult of the Martyrs: the Liber Peristephanon of Prudentius, Ann Arbor, 1993; P.-Y. Fux, Les sept passions de Prudence (Peristephanon 2.5.9.11-14): introduction générale et commentaire, Fribourg, 2003. 
utterly destroy even his bones, so that his corpse shall have no grave for the common herd to venerate and set on it a martyr's epitaph. ${ }^{60}$

Unfortunately, due to lack of source, it is impossible to ascertain whether the governor hoped to preclude the veneration towards the relic of Vincent. In the 410s, Augustine indicated the destruction and disposal of his body in his sermons for Vincent, ${ }^{61}$ but again, there is no mention of preventing the cult of the relic.

Second, in the hymn of Romanus, martyred in 303 in Antioch, the governor addressed him with the following:

[Y] ou are the disturber of the city's peace, like a stormy wind disordering the fickle mob's inconstant minds so that the ignorant rabble shall not submit to the law. The uneducated multitude has believed a doctrine that appeals to the people under the guise of glory, so that they aver that they are to be made immortal through all time if, like the Giants, they make war on the gods and in defeat are buried under flaming mountains. ${ }^{62}$

Concerning this case, the governor seems to refer to the cult of the hero. However, and more importantly, these intimidating words towards the martyr were probably fabricated by Prudentius himself. Eusebius' History of the Martyrs in Palestine, which is the earliest document concerning the martyrdom of Roma-

60 Prudentius, Peristephanon, 5.385-392 (ed. by J. Bergman (CSEL, 61), Vienna - Leipzig, 1926): "Sed restat illud ultimum: inferre poenam mortuo, feris cadauer tradere canibusue carpendum dare. Iam nunc et ossa extinxero, ne sit sepulcrum funeris, quod plebs gregalis excolat titulumque figat martyris." Translation from H.J. Thomson, Prudentius, vol. 2 (LCL, 398), Cambridge, MA - London, 1953, p. 193.

$61 \quad$ Augutine, Sermo 275.3 (ed. by J.P. Migne, PL, 38, col. 1254-1255); 277.6 (Ibid., col. 12571268). Augustine refers to Vincentius in his six sermons (Sermo 4; 274-277; 277A): V. Saxer, "La Passion de S. Vincent diacre dans la première moitié du Ve Siècle: essai de reconstitution," Revue des études augustiniennes, 35 (1989), pp. 275-297 (see p. 279);J.E. Rotelle (ed.), Sermons, 1, (The Works of Saint Augustine: a translation for the 21st century, III/1), New York, 1990, pp. 138-163, 185-213; idem (ed.), Sermons, 8 (The Works of Saint Augustine: a translation for the 21st century, III/8), New York, 1994, pp. 23-49.

62 Prudentius, Peristephanon, 10.78-85: "tu uentilator urbis et uulgi leuis procella mentes inquietas mobiles, ne se inperita turba dedat legibus. Populare quiddam sub colore gloriae inlitterata credidit frequentia, ut se per aeuum consecrandos autument, si bella diuis ceu gigantes inferant uictique flammis obruantur montium". Translation from Thomson, Prudentius, p. 235 . 
nus, makes no reference to such words. ${ }^{63}$ Thus, one could argue that Prudentius presented the governor as a critic of Christianity, drawing on the image of the pagan persecutor in the time of the "Great Persecution."

The presented example from the texts of Prudentius clarifies that the image of the pagans as being hostile towards the veneration of martyrs was fabricated by the end of the fourth century. This finding helps us better understand the texts of Ammianus. As mentioned earlier, it is unlikely that the mobs in Alexandria, who brutally abused the body of George, intended to prevent the cult of the martyr, since such an image of the pagans was probably created by the time that Ammianus wrote about the incident. ${ }^{64}$ Furthermore, if it is correct to assume that this account is based on Christian sources, then it definitely reflects the images of the cruel pagans fabricated by Christians. If not, it becomes evident that Ammianus, despite not being a Christian himself, agreed with this image in his texts, thus allowing us to acknowledge the Christianised view of pagans in the work of the last great Latin historian.

\section{5}

\section{Conclusion}

This paper focused on three main issues regarding the brutal murder of George of Cappadocia and the question of whether the pagans attempted to prevent the cult of the martyr. First, an examination of the sources regarding the murderers of George found that the Alexandrian crowd did not only consist of pagans. Instead, everyone who had suffered from the tyranny of George could be possible assailants. Second, Ammianus' report that the intention of the people was to defile the victims' remains is highly contested. Regarding fourth century Alexandria, it is impossible to find any evidence that refers to such an attempt. Third, his text exposed a somewhat ruthless image of pagans as presented by Christian authors such as Prudentius. It is possible that this violent pagan image stems from the memory of the "Great Persecution." Finally, it is hoped that the findings and implications of this paper will encourage a reconsideration of the relationship between pagans and Christians during the Late Antiquity.

63 Eusebius, De Martyribus Palestinae (short recension), 2 (ed. by S. Schwartz (GCS, 9), Leipzig, 1908, S. 907-950); De Martyribus Palestinae (long recension), trans. by W. Cureton, History of the Martyrs in Palestine, by Eusebius, Bishop in Caesarea discovered in a very ancient Syriac manuscript, London, 1861, pp. 6-8.

64 Ammianus wrote his Res Gestae around 390. See A. Cameron, "Review: Ammianus and the Historia Augusta by Ronald Syme," Journal of Romans Studies, 61 (1971), pp. 255-267 (see pp. 259-262); Matthews, Roman Empire of Ammianus, pp. 17-32; Kelly, Ammianus the allusive historian, pp. 8-9. 